\title{
Oxidative Potential of Selected PM Components ${ }^{\dagger}$
}

\author{
Elena Conte, Silvia Canepari, Daniele Frasca and Giulia Simonetti * \\ Department of Chemistry, Sapienza University of Rome, 00185 Rome, Italy; elenaconte90@gmail.com (E.C.); \\ silvia.canepari@uniroma1.it (S.C.); daniele.frasca@uniroma1.it (D.F.) \\ * Correspondence: giulia.simonetti@uniroma1.it; Tel.: +39-339-7220068 \\ + Presented at the 2nd International Electronic Conference on Atmospheric Sciences, 16-31 July 2017; \\ Available online: http://sciforum.net/conference/ecas2017.
}

Published: 17 July 2017

\begin{abstract}
The role of the single PM components in inducing the catalytic generation of reactive oxygen species (ROS), has not yet been clarified. Different a-cellular assay are currently used in the literature for the determination of the PM oxidative potential (OP), which is considered as a predictive index of its capacity to generate ROS in biological organisms. In order to better understand the existing correlations between $\mathrm{PO}$ and PM generated by specific emission sources, the water soluble and insoluble fractions of seven dust coming from specific sources were chemically characterised and analysed by three PO assays: the dithiothreitol (DTT, the acid ascorbic (AA) and the $2^{\prime}, 7^{\prime}$-dichlorofluorescin (DCFH) assays. PO and chemical data were elaborated by principal constituent analysis. The three methods responded in a very different way to each dust; they are then no-interchangeable and probably none of them is able to correctly predict the ROS generation in biological organisms. DTT was particularly sensitive to organic compounds, while AA was mostly influenced by inorganic components. DCFH results are more difficult to interpret and need to be further deepened. Furthermore, the results confirmed the important role played by the insoluble components of dusts in generating oxidative processes.
\end{abstract}

Keywords: particulate matter; oxidative potential; 2',7'-dichlorofluorescin (DCFH) assay; dithiothreitol (DTT) assay; acid ascorbic (AA) assay

\section{Introduction}

Numerous epidemiological studies have established a consistent associations between particulate matter (PM) concentrations and increased morbidity and mortality due to respiratory and cardiovascular diseases [1-3]. Furthermore, various experimental studies provide a plausible correlation between the PM oxidative capacity and its toxicity [3-9]. Several toxicological studies documented the ability of the inhaled PM to cause oxidative stress, including PM's ability to induce pro-inflammatory effects in nose, lung and cardiovascular system $[4,10,11]$. Oxidative stress occurs when there is an imbalance between the level of reactive oxygen species (ROS) or free radicals and the natural antioxidant defence of the biological system. ROSs include families of free radicals, ions and molecules centred on oxygen or related. The free radical family includes peroxide radicals of hydroxyl, hydroperoxide and organic peroxide. Ions such as superoxides, hypochlorites and peroxynitrione, and molecules such as hydrogen peroxide, organic and inorganic peroxides, are enclosed in the circle of Reactive Oxygen Species. Usually ROS formation in cells occurs through the reduction of oxygen from biological reducing agents such as NADH and NADPH. Electron transfer enzymes and active redox chemical species such as redox active chemicals and organic metals $[10,12]$ assist these processes. It is now commonly thought that ROS can damage lipids, proteins and membrane DNA, can cause cell death by necrotic or apoptotic processes. High levels of oxidative stress cause a change in the redox status of the cells. 
However, all this studies don't allow a complete understanding of the relationship between the toxicological mechanisms and the physic-chemical properties of PM. One of the main difficulty in the identification of these relationships regards the complexity of the matrix in question. In fact, the particulate matter consists of a complex heterogeneous mixture of solid and liquid particles varying in size and chemical composition, emitted by several different sources. Therefore, the identification of the toxic components of PM and their attribution to a specific emission sources is a challenging task of the environmental chemistry.

In the literature, several methods are used to measure the so-called aerosol oxidative potential (PO). The objective of these a-cellular assays is to provide a proxy of the oxidative capability of PM samples.

We selected three of the most common methods typically used in this field: the dithiothreitol (DTT), the ascorbic acid (AA) and the 2',7'-dichlorofluorescin (DCFH) assays.

The DDT and the AA assays consist in the controlled incubation of the anti-oxidant (DTT or AA) in an aqueous extracts of $\mathrm{PM}$ under controlled conditions $\left(\mathrm{T}=37^{\circ} \mathrm{C}\right.$ and $\left.\mathrm{pH} 7.4\right)[13,14]$ and in the measurement of its depletion over time, by following the decrease of absorbance at the wavelengths of 412 and $265 \mathrm{~nm}$, respectively. The antioxidant loss rate represents the ability of the aerosol redoxactive species to transfer electrons from DTT or AA to oxygen $\left(\mathrm{O}_{2}\right)$.

The DTT is considered a chemical surrogate of cellular reductants, such as NADH or NADPH, which reduces $\mathrm{O}_{2}$ to superoxide anion $\left(\mathrm{O}^{-}\right)$and induces oxidative stress [15].

At the opposite, the ascorbic acid is a physiological antioxidant that prevent the oxidation of lipids and proteins [16].

On the contrary, the $2^{\prime}, 7^{\prime}$-dichlorofluorescin (DCFH) assay is a direct detection method performed by a fluorescence technique using a specific florigenic probe. In this assay, the nonfluorescent DCFH is oxidized to the fluorescent dichlorofluorescein (DCF) by ROS in the presence of horseradish peroxidase (HRP). The formed DCF can be easily measured by fluorescence at the excitation and emission wavelengths of 485 and $530 \mathrm{~nm}$ [17-19]. The ROS concentration may be then calculated in terms of $\mathrm{H}_{2} \mathrm{O}_{2}$ equivalent. This assay was widely applied also for the ROS determination in biological cells [20-23].

Although these metods are frequently applied to the study of PM biological effects, there is still a gap of knowledge about the relationship that links PM chemical composition and the oxidative potential results obtained this assays [24].

In this work, we use these selected methods for the determination of the PO of seven types of dusts coming from different emission sources and characterized by a very different chemical composition, with the aim of better investigating the role of the singles components of PM in generating PO.

The chosen dusts, already used in a precedent work for the evaluation of the in vivo genotoxic effects and oxidative stress on specimens of Echinogammarus veneris, represent specific PM sources [25]. Besides the certificate material NIST1648 (urban dust; UD), we considered some of the major PM components. Soil (S) is the major natural component of PM, while road dust (RD) is a complex mixture of natural soil particles and dust formed by the mechanical abrasion of vehicles components (brakes, tyres) and road surface (asphalt) deposited on the road. Its contribute to PM is mainly due to the re-suspention caused by vehicular traffic and is particularly relevant in urban areas [26,27]. Brake dust (BD), produced by brake pads lining, is the part of $\mathrm{RD}$ containing the highest concentration of heavy metals and other toxic elements [28,29]. Saharan dust (SD) constitutes a major contribute to PM in the Mediterranean area during long-range transport from North Africa [26,27]. These events are usually responsible of high $\mathrm{PM}_{10}$ concentration and recently re-considered as potentially harmful to human health [30]. Pellet ash (PA) is a component whose contribute to PM is increasing in the last years because of the increased diffusion of pellet stoves for domestic heating. Several studies recognized the damage caused by this emission source that containing toxicants as polycyclic aromatic hydrocarbons and toxic elements [31]. Finally, coke (C) contains very high concentrations of organic species, which have been considered as responsible for genotoxic and oxidative stress effects [32,33]. 
We also decided to deepen the relationship between the solubility of the chemicals species and the PO. In fact, precedent studies showed the ability of the species present in the insoluble part of the dust to generate oxidative stress [25].

In most literature studies, the PO analysis are performed only on the soluble fraction of samples. A few recent studies, however, evidence that the role of the insoluble fraction of PM in generating oxidative stress is not negligible $[25,34,35]$.

\section{Experiments}

\subsection{Dust Collection}

All the dusts were collected in different and specific areas. Soil dust (S) was sampled in rural areas around the city of Rome, within a perimeter of $50 \mathrm{~km}$; road dust (RD) was obtained by collecting the dust deposited on the road surface at several traffic sites in the centre of Rome (Central Italy); brake dust (BD) was collected from the brake linings of three different cars; Saharan dust (SD) was collected in Algeria, in the north of the Sahara desert. The ash produced by pellet burning (PA) was collected inside the hood of a domestic pellet stove. Coke (C) was collected near a refinery plant, on the ground in the proximity of a coal park. All dusts were homogenized and sieved at 50 micron (Giuliani, Torino, Italy) before use. In addition to the above dust samples, certificate material NIST1648a was used as urban dust (UD) sample. All the samples were homogenized and sieved at 50 micron. More details about the collection of these dust samples are given in [29,36].

\subsection{Chemical Characterization of Dusts}

A complete chemical characterization (macro-and micro-elements, EC/OC, inorganic ions) of all the considered dusts had already been reported in [25]. In this precedent work we analysed all dusts by ion chromatography (ICS1000; Dionex Co., Sunnyvale, CA, USA) for the quantification of $\mathrm{Na}^{+}$, $\mathrm{Mg}^{2+}, \mathrm{Ca}^{2+}, \mathrm{NH}_{4}{ }^{+}, \mathrm{Cl}^{-}, \mathrm{NO}_{2}{ }^{-}, \mathrm{NO}_{3}{ }^{-}$and $\mathrm{SO}_{4}{ }^{2-}$ and by inductively coupled plasma-mass spectroscopy (ICP-MS; Bruker 820, Bremen, Germany) for the determination of As, B, Cd, Ce, Co, Cs, Cu, La, Mn, $\mathrm{Mo}, \mathrm{Ni}, \mathrm{Pb}, \mathrm{Rb}, \mathrm{Sb}, \mathrm{Se}, \mathrm{Sn}, \mathrm{Sr}, \mathrm{Tl}, \mathrm{V}, \mathrm{Zn}$ and $\mathrm{Zr}$ in their soluble and insoluble fractions. We also used thermo-optical analyser (ECOC analyser, Sunset Laboratory, OR, USA) for the determination of the total organic and elemental carbon. In this work, the chemical characterization of dusts was completed by the determination of the water-soluble organic carbon (WSOC) that was analysed by TOC-VCSH (Shimadzu) by using the NPOC (non-purgeable organic carbon) procedure. Before the instrumental analysis of WSOC, samples were extracted in $20 \mathrm{~mL}$ of Milli-Q water and subjected to ultrasounds for $30 \mathrm{~min}$. Solutions were then filtrated through a nitrocellulose filter (Millipore membrane, pore size $0.45 \mu \mathrm{m})$ and $100 \mu \mathrm{L}$ of chloride acid (10M) were added.

Results of the chemical characterization of the selected dusts are reported in Tables 1 (soluble species) and 2 (insoluble species).

\subsection{Extraction Procedure}

$50 \mathrm{mg}$ of all the dusts were weighted (Analytical Balance Gibertini Elettronica E505, $0.01 \mathrm{mg}$ sensitivity) and then solubilized in $50 \mathrm{~mL}$ of water. Subsequently the solutions were sonicated (FALC ULTRASONIC UTA) and then centrifuged (30 min at 10,000 rpm and $25^{\circ} \mathrm{C}$; ALC MILTISPEED REFRIGERATED CENTRIFUGEPK131R) in order to obtain the soluble and the insoluble fractions. The soluble part was filtered through nitrocellulose filter (MF membrane, pore size $0.45 \mu \mathrm{m}$ ) and immediately analysed for their oxidative potential in the soluble fraction. The insoluble part was resuspended in $50 \mathrm{~mL}$ of water; the suspension was again analyzed for $\mathrm{OP}$ (residual fraction) with the same procedures used for the soluble fraction and filtered just prior to the instrumental analysis. In the same condition we are analysed the background too. For each sample, six replicates were performed. 


\subsection{Oxidative Potential Assays}

\subsubsection{DTT Procedure}

Five $0.7 \mathrm{~mL}$ aliquots of the PM sample (soluble or residua fractions) were added of $0.2 \mathrm{~mL}$ of phosphate buffer $(1 \mathrm{M})$ and of $0.1 \mathrm{~mL}$ of DTT $1 \mathrm{mM}$ and incubated in a thermostatic bath (HAAKE DC3 Fisons) at $37^{\circ} \mathrm{C}$. At regular intervals (at times: $0,5^{\prime}, 10^{\prime}, 15^{\prime}, 20^{\prime}$ ), $1 \mathrm{~mL}$ of TCA $10 \%$ was successively added to one of the aliquots to stop the reaction. $1 \mathrm{~mL}$ of each solution was then mixed with $2 \mathrm{~mL}$ of Tris-buffer ( $0.08 \mathrm{M}$ with $4 \mathrm{mM}$ EDTA) and $50 \mu \mathrm{L}$ of DTNB (5,50-dithiobis-(2-nitrobenzoic acid), $0.2 \mathrm{mM}$ ) After $5 \mathrm{~min}$, the absorbance of the solutions was read at $412 \mathrm{~nm}$ by UV-Vis spectrophotometry (UV-Vis; Varian Cary 50 UV-VIS Spectrometer). According to ref [14] OP was calculated as DTT consumption rate per unit of air volume $\left(\mathrm{nmolmin}{ }^{-1} \cdot \mathrm{m}^{-3}\right)$, or per unit of PM mass $\left(\mathrm{nmolmin}{ }^{-1} \cdot \mu \mathrm{g}^{-1}\right)$. Final DTT activity is calculated as follows (1):

$$
\begin{aligned}
& \sigma \mathrm{DTT}=-\sigma \mathrm{Abs} \times \frac{N_{0}}{\mathrm{Abs}_{0}}, \\
& \mathrm{DTT}=\frac{\sigma \mathrm{DTT}_{\mathrm{s}}-\sigma \mathrm{DTT}_{\mathrm{b}}}{\frac{V_{\mathrm{a}}}{V_{\mathrm{e}}} \times V_{\mathrm{p}}} .
\end{aligned}
$$

\subsubsection{DCFH Procedure}

The DCFH-DA solution were prepared by dissolving $4.873 \mathrm{mg}$ of reagent in $5 \mathrm{~mL}$ of $\mathrm{CH}_{3} \mathrm{CH}_{2} \mathrm{OH}$ in the dark. Then, $20 \mathrm{~mL} \mathrm{NaOH} 0.01 \mathrm{M}$ were added to favour the de-acetalization reaction; the solution was then kept in the dark at room temperature for $30 \mathrm{~min}$ before use.

The HRP solution $(0.5$ units $/ \mathrm{mL})$ was prepared by dissolving proper weighted amount of the commercial product (Type VI, essentially salt-free, lyophilized powder, $\geq 250$ units $/ \mathrm{mg}$ solid) in $1 \mathrm{~L}$ of $25 \mathrm{mM}$ phosphate buffer at $\mathrm{pH} 7.4$ and incubated at $37{ }^{\circ} \mathrm{C}$ for $15 \mathrm{~min}$. Aliquots of $5 \mathrm{~mL}$ of the buffered HRP solution were added to $1.5 \mathrm{~mL}$ of sample (soluble or residual fraction), and $125 \mu \mathrm{L}$ of $5 \mu \mathrm{M} \mathrm{DCFH}$ and the solution was kept at $37^{\circ} \mathrm{C}$ for $15 \mathrm{~min}$. The intensity of the fluorescence radiation at $530 \mathrm{~nm}$ was then measured by (Jasco FP-920 Fluorescence detector). The excitation wavelength was $427 \mathrm{~nm}$. The calibration curve was obtained daily by standard $\mathrm{H}_{2} \mathrm{O}_{2}$ solutions $\left(5 \times 10^{-6}, 1 \times 10^{-7}, 2 \times\right.$ $10^{-7}, 5 \times 10^{-7}, 1 \times 10^{-6} \mathrm{M}$ ) and the fluorescence intensity obtained with the samples was converted into equivalent $\mathrm{H}_{2} \mathrm{O}_{2}$ concentrations [37].

\subsubsection{AA Procedure}

$2.4 \mathrm{~mL}$ of sample (soluble or residual fraction) were added to $0.3 \mathrm{~mL}$ of phosphate buffer $0.5 \mathrm{mM}$ ( $\mathrm{pH}$ 7.4) and $100 \mu \mathrm{L}$ of ascorbic acid ( $2 \mathrm{mM} \mathrm{AA}$ ). The absorbance of the sample, thermostated at $37^{\circ} \mathrm{C}$, was then followed for $20 \mathrm{~min}$ by UV-Vis spectroscopy at $265 \mathrm{~nm}$. According to [14], OP was calculated AA consumption rate per unit of air volume (nmolmin-1 m-3), or per unit of PM mass (nmolmin-1 $\mu \mathrm{g}-1$ ). Final AA activity is calculated as follows (2):

$$
\begin{gathered}
\sigma \mathrm{AA}=-\sigma \mathrm{Abs} \times \frac{N_{0}}{\mathrm{Abs} 0_{0}}, \\
\mathrm{AA}=\frac{\sigma \mathrm{AA}_{\mathrm{s}}-\sigma \mathrm{AA} \mathrm{A}_{\mathrm{b}}}{\frac{V_{\mathrm{a}}}{V_{\mathrm{e}}} \times V_{\mathrm{p}}} .
\end{gathered}
$$


Table 1. * Chemical composition of the dust samples relative to the soluble fraction.

\begin{tabular}{|c|c|c|c|c|c|c|c|c|c|}
\hline & & & Nist1648a & $\begin{array}{c}\text { Brake } \\
\text { Dust }\end{array}$ & Coke & Road Dust & $\begin{array}{c}\text { Saharian } \\
\text { Dust }\end{array}$ & $\begin{array}{c}\text { Soil } \\
\text { Dust }\end{array}$ & $\begin{array}{c}\text { Ash } \\
\text { Pellet }\end{array}$ \\
\hline Technique & UoM & & Mean & Mean & Mean & Mean & Mean & Mean & Mean \\
\hline ICP-MS & $\mathrm{g} / \mathrm{Kg}$ & $\mathrm{Al}$ & 0.28 & 0.162 & 0.9 & 1.76 & 0.4 & 0.69 & 0.097 \\
\hline ICP-MS & $\mathrm{mg} / \mathrm{Kg}$ & As & 81 & 1.13 & 0.60 & 2.1 & 1.1 & 7.9 & 2.9 \\
\hline ICP-MS & $\mathrm{mg} / \mathrm{Kg}$ & B & 19.0 & 8.5 & 2.8 & 1.7 & 11.0 & 0.4 & 590 \\
\hline IC & $\mathrm{g} / \mathrm{Kg}$ & $\mathrm{Ca}$ & 9.6 & 27.9 & 1.29 & 48 & 17.1 & 139 & 74 \\
\hline ICP-MS & $\mathrm{mg} / \mathrm{Kg}$ & $\mathrm{Cd}$ & 48 & 0.30 & 0.02 & 0.07 & 0.12 & 0.019 & 13 \\
\hline ICP-MS & $\mathrm{mg} / \mathrm{Kg}$ & $\mathrm{Ce}$ & 0.180 & 0.106 & 0.022 & 2.2 & 0.16 & 0.30 & 0.041 \\
\hline IC & $\mathrm{mg} / \mathrm{Kg}$ & $\mathrm{Cl}$ & 4540 & 660 & 19 & 190 & 1220 & 41 & 1090 \\
\hline ICP-MS & $\mathrm{mg} / \mathrm{Kg}$ & Co & 5.40 & 1.06 & 0.05 & 0.62 & 0.18 & 0.24 & 4.3 \\
\hline ICP-MS & $\mathrm{mg} / \mathrm{Kg}$ & $\mathrm{Cr}$ & 28.0 & 24.7 & 0.83 & 13.7 & 4.0 & 3.8 & 4.6 \\
\hline ICP-MS & $\mathrm{mg} / \mathrm{Kg}$ & Cs & 0.003 & 0.210 & 0.010 & 0.212 & 0.020 & 0.28 & 2.7 \\
\hline ICP-MS & $\mathrm{mg} / \mathrm{Kg}$ & $\mathrm{Cu}$ & 275 & 765 & 13 & 9 & 3 & 1.2 & 37 \\
\hline ICP-MS & $\mathrm{g} / \mathrm{Kg}$ & $\mathrm{Fe}$ & 5.9 & 6.4 & 1.0 & 0.46 & 0.24 & 0.43 & 0.02 \\
\hline ICP-MS & $\mathrm{mg} / \mathrm{Kg}$ & $\mathrm{La}$ & 0.160 & 0.067 & 0.011 & 1.585 & 0.111 & 0.17 & 0.062 \\
\hline ICP-MS & $\mathrm{mg} / \mathrm{Kg}$ & $\mathrm{Mn}$ & 340 & 119.7 & 6.4 & 29.7 & 6.2 & 25 & 1751 \\
\hline ICP-MS & $\mathrm{mg} / \mathrm{Kg}$ & Mo & 5.70 & 3.80 & 0.827 & 0.038 & 0.009 & 0.053 & 3.6 \\
\hline ICP-MS & $\mathrm{mg} / \mathrm{Kg}$ & $\mathrm{Ni}$ & 20.0 & 3.97 & 1.88 & 1.15 & 0.8 & 1.6 & 9 \\
\hline ICP-MS & $\mathrm{mg} / \mathrm{Kg}$ & $\mathrm{Pb}$ & 2424 & 5.94 & 9.85 & 5.36 & 2.5 & 0.54 & 0.42 \\
\hline ICP-MS & $\mathrm{mg} / \mathrm{Kg}$ & $\mathrm{Rb}$ & 26.4 & 5.6 & 0.6 & 0.68 & 6.4 & 0.8 & 310 \\
\hline ICP-MS & $\mathrm{mg} / \mathrm{Kg}$ & $\mathrm{Sb}$ & 26.0 & 13.9 & 0.16 & 0.047 & 0.415 & 0.002 & 1.6 \\
\hline ICP-MS & $\mathrm{mg} / \mathrm{Kg}$ & Se & 5.7 & 0.27 & 0.37 & 0.44 & 1.2 & 0.15 & 23 \\
\hline ICP-MS & $\mathrm{g} / \mathrm{kg}$ & $\mathrm{Si}$ & 1.41 & 0.52 & 0.4 & 5.2 & 1.48 & 0.32 & 0.39 \\
\hline ICP-MS & $\mathrm{mg} / \mathrm{Kg}$ & Sn & 0.310 & 1.62 & 0.130 & 0.056 & 0.002 & 0.09 & 0.46 \\
\hline ICP-MS & $\mathrm{mg} / \mathrm{Kg}$ & $\mathrm{Sr}$ & 125 & 98 & 4 & 164 & 350 & 150 & 542 \\
\hline ICP-MS & $\mathrm{mg} / \mathrm{Kg}$ & $\mathrm{Ti}$ & 1.20 & 0.98 & 13 & 7.6 & 8.6 & 13.1 & 0.061 \\
\hline ICP-MS & $\mathrm{mg} / \mathrm{Kg}$ & $\mathrm{Tl}$ & 0.008 & 0.04 & 0.002 & 0.026 & 0.03 & 0.014 & 1.05 \\
\hline ICP-MS & $\mathrm{mg} / \mathrm{Kg}$ & V & 89 & 1.29 & 1.08 & 2.14 & 0.84 & 1.2 & 3.7 \\
\hline ICP-MS & $\mathrm{mg} / \mathrm{Kg}$ & $\mathrm{Zn}$ & 1023 & 2120 & 100 & 673 & 7 & 18 & 525 \\
\hline ICP-MS & $\mathrm{mg} / \mathrm{Kg}$ & $\mathrm{Zr}$ & 0.270 & 2.31 & 0.018 & 4.83 & 0.007 & 0.58 & 0.07 \\
\hline IC & $\mathrm{g} / \mathrm{Kg}$ & $\mathrm{NO}_{2-}^{-}$ & $<0.1$ & $<0.1$ & $<0.1$ & $<0.1$ & $<0.1$ & $<0.1$ & 6.5 \\
\hline IC & $\mathrm{g} / \mathrm{Kg}$ & $\mathrm{NO}_{3}^{-}$ & 47 & 4.0 & $<0.1$ & $<0.1$ & $<0.1$ & $<0.1$ & 2.2 \\
\hline IC & $\mathrm{g} / \mathrm{Kg}$ & $\mathrm{SO}_{4}^{-}$ & 154 & 5.9 & $<0.1$ & $<0.1$ & 28.0 & 0.9 & 37 \\
\hline TOC & $\mathrm{g} / \mathrm{Kg}$ & WSOC & 22 & 5.7 & 9.5 & 2.1 & 0.53 & 0.3 & 22 \\
\hline
\end{tabular}

* The values report in the Table 1 present a relative standard deviation $<10 \%$ for all the elements analysed.

Table 2. ${ }^{*}$ Chemical composition of the dust samples relative to the insoluble fraction.

\begin{tabular}{|c|c|c|c|c|c|c|c|c|c|}
\hline & & & Nist1648a & Brake Dust & Coke & Road Dust & Saharian Dust & Soil Dust & Ash Pellet \\
\hline Technique & UoM & & Mean & Mean & Mean & Mean & Mean & Mean & Mean \\
\hline XRF/ICP-MS & $\mathrm{g} / \mathrm{Kg}$ & $\mathrm{Al}$ & $34 *$ & 14.7 & 12 & 70 & 69 & 9.7 & 6.1 \\
\hline ICP-MS & $\mathrm{mg} / \mathrm{Kg}$ & As & 35.0 & 18.0 & 0.52 & 1.6 & 0.3 & 87 & 2.3 \\
\hline ICP-MS & $\mathrm{mg} / \mathrm{Kg}$ & B & 44 & 23.1 & 0.7 & 48.2 & 2.2 & 1.2 & 235 \\
\hline XRF/IC & $\mathrm{g} / \mathrm{Kg}$ & $\mathrm{Ca}$ & $53 *$ & 12.9 & 1.38 & 29 & 15 & 131 & 74 \\
\hline ICP-MS & $\mathrm{mg} / \mathrm{Kg}$ & $\mathrm{Cd}$ & 26 & 0.73 & 0.05 & 0.28 & 0.76 & 0.072 & 20 \\
\hline ICP-MS & $\mathrm{mg} / \mathrm{Kg}$ & $\mathrm{Ce}$ & 546 & 26.2 & 0.3 & 109 & 1.0 & 10 & 9 \\
\hline XRF/IC & $\mathrm{mg} / \mathrm{Kg}$ & $\mathrm{Cl}$ & - & - & 1.0 & - & 100 & - & - \\
\hline ICP-MS & $\mathrm{mg} / \mathrm{Kg}$ & Co & 13.0 & 13.9 & 1.02 & 10.8 & 0.55 & 1.6 & 9 \\
\hline XRF/ICP-MS & $\mathrm{mg} / \mathrm{Kg}$ & $\mathrm{Cr}$ & $374 *$ & 3083 & 9.6 & 57 & 48 & 36 & 20.4 \\
\hline ICP-MS & $\mathrm{mg} / \mathrm{Kg}$ & Cs & 1.70 & 2.99 & 0.04 & 20.90 & 0.005 & 2.5 & 0.43 \\
\hline ICP-MS & $\mathrm{mg} / \mathrm{Kg}$ & $\mathrm{Cu}$ & 336 & 4286 & 43 & 71 & 10 & 13 & 204 \\
\hline XRF/ICP-MS & $\mathrm{g} / \mathrm{Kg}$ & $\mathrm{Fe}$ & $33^{*}$ & 198 & 16 & 59 & 40.7 & 3.5 & 3.7 \\
\hline ICP-MS & $\mathrm{mg} / \mathrm{Kg}$ & $\mathrm{La}$ & 32 & 12.7 & 0.3 & 54.4 & 26.5 & 5 & 5.5 \\
\hline ICP-MS & $\mathrm{mg} / \mathrm{Kg}$ & $\mathrm{Mn}$ & 450 & 1093 & 40 & 475 & 22.5 & 96 & 17869 \\
\hline ICP-MS & $\mathrm{mg} / \mathrm{Kg}$ & Mo & 8.30 & 171 & 75.5 & 0.83 & 0.15 & 0.65 & 1.2 \\
\hline ICP-MS & $\mathrm{mg} / \mathrm{Kg}$ & $\mathrm{Ni}$ & 61.0 & 108 & 355 & 14.2 & 5.1 & 9 & 28 \\
\hline ICP-MS & $\mathrm{mg} / \mathrm{Kg}$ & $\mathrm{Pb}$ & 4127 & 677 & 8.9 & 67.0 & 0.010 & 11 & 55 \\
\hline ICP-MS & $\mathrm{mg} / \mathrm{Kg}$ & $\mathrm{Rb}$ & 26 & 27 & 0.5 & 240 & 1.1 & 10 & 31 \\
\hline ICP-MS & $\mathrm{mg} / \mathrm{Kg}$ & $\mathrm{Sb}$ & 23.4 & 292 & 4.07 & 0.204 & 2.08 & 0.4 & 1.7 \\
\hline ICP-MS & $\mathrm{mg} / \mathrm{Kg}$ & Se & 20 & 9.0 & 9.0 & 3.1 & 0.37 & 11 & 0.02 \\
\hline XRF/ICP-MS & $\mathrm{g} / \mathrm{Kg}$ & $\mathrm{Si}$ & 128 * & 26 & 21 & 173 & 228 & 16 & 6.5 \\
\hline ICP-MS & $\mathrm{mg} / \mathrm{Kg}$ & Sn & 55.0 & 1419 & 14.7 & 1.97 & 0.02 & 2.7 & 21 \\
\hline ICP-MS & $\mathrm{mg} / \mathrm{Kg}$ & $\mathrm{Sr}$ & 90 & 159 & 6 & 674 & 2.7 & 375 & 717 \\
\hline XRF/ICP-MS & $\mathrm{mg} / \mathrm{Kg}$ & $\mathrm{Ti}$ & $3900 *$ & 526 & 894 & 3835 & 4532 & 241 & 18.9 \\
\hline ICP-MS & $\mathrm{mg} / \mathrm{Kg}$ & $\mathrm{Tl}$ & 1.9 & 0.3 & 0.03 & 1.30 & 0.004 & 0.11 & 0.9 \\
\hline ICP-MS & $\mathrm{mg} / \mathrm{Kg}$ & V & 38 & 7.6 & 557 & 118 & 4.9 & 10 & 8 \\
\hline ICP-MS & $\mathrm{mg} / \mathrm{Kg}$ & $\mathrm{Zn}$ & 1200 & 3197 & 160 & 318 & 40 & 86 & 1157 \\
\hline ICP-MS & $\mathrm{mg} / \mathrm{Kg}$ & $\mathrm{Zr}$ & 28.0 & 87 & 11.1 & 89 & 9.4 & 12 & 10 \\
\hline ECOC & $\mathrm{g} / \mathrm{Kg}$ & $\mathrm{EC}$ & 23.0 & 17 & 310 & 0.07 & & & \\
\hline $\mathrm{ECOC} / \mathrm{TOC}$ & $\mathrm{g} / \mathrm{Kg}$ & WIOC & 83 & 30 & 146 & 12 & 0.10 & 41 & 4 \\
\hline
\end{tabular}

* The values report in the Table 2 present a relative standard deviation $<10 \%$ for all the elements analysed. 


\section{Results}

Tables 1 and 2 report the concentrations of the analyzed chemical species in the soluble and insoluble fraction of the selected dusts respectively. Each dust has a different and specific chemical composition: the inorganic fraction are prevalent in all the samples and, in particular, $\mathrm{Al}, \mathrm{Cu}$, and $\mathrm{Si}$ are abundant in urban dust, road dust, Saharan dust, and soil, while Fe and EC are the main constituents of brake and coke dust, respectively; In addition, soluble inorganic ions represent an important fraction in NIST, soil dust and pellet. For the organic fraction, OC is predominant in coke, urban dust and lesser extent in road dust, brake dust, soil and pellets and is negligible in the Sahara. WSOC present its maximum concentrations in NIST and pellets dusts. It is important to underline that the organic carbon (OC) is a major component of aerosol and it can represent from 10 to $70 \%$ of the total mass of fine aerosol: understanding the sources of organic carbon (OC) has become an important focus for investigators. The water-soluble fraction of organic carbon (WSOC) is usually responsible for a large part (20-70\%) of OC. WSOC is generally composed of a mixture of highmolecular-weight carboxylic, keto/carbonyl, amino/imino, and nitro multifunctional organic compounds, and is frequently referred to as humic-like substances (HULIS) as well as smaller organic molecules, such as anhydrides, sugars and keto- and $\alpha, \omega$-dicarboxylic acids (Graham et al., 2002; Cappiello et al., 2003; Fuzzi et al., 2006; Duarte et al., 2007; Ding et al., 2008). The water-soluble components of particulate matter are considered to be more easily absorbed into lung fluids, potentially enhancing their ability to produce adverse human health effects.

In addition, ICP-MS analysis show that urban dust, brake dust and pellets contain the highest amount of heavy metals. $\mathrm{Pb}$ and $\mathrm{Mn}$ concentrations are particularly high in both the brake and pellet dusts, while $\mathrm{Cu}, \mathrm{Sb}$ and $\mathrm{Sn}$ in the brake dust only. Lower concentrations of trace elements are found in road dust, coke and soil (overall $0.3 \%, 0.1 \%$ and $0.1 \%$, respectively). However, the lowest concentrations of trace elements are found in the Saharan dust (0.04\%). Finally, the coke showed the highest concentrations of $\mathrm{Ni}$ and $\mathrm{V}$, while the soil dust is particularly rich in As.

It is worth noting that the same element can be found as solvated ion or as suspended solid, depending on the solubility of the chemical species that contain it. The results show that most of the elements are present mainly as insoluble species. However, a very significant variation of the solubility distribution among the considered dusts is observed for some elements. For example, As is present mainly as soluble species in UD and as insoluble species in S, while Rb is almost completely soluble in PA and insoluble in RD. In general, according to the results of some previous environmental studies, the elemental solubility tends to be higher when the dust is generated by combustive processes, as PA and, at least in part, UD [27,38].

How the Figure 1 shows, the three methods give different results for each types of dusts. In agreement to previous studies [24] this result confirms that the chemical composition plays the most important role in the determination of the oxidative processes induced by PM. The DCFH assay showed to be the less selective method and lead to relevant PO values for all the considered dusts. Road dust, which is rich in both inorganic and organic soluble components, produced the highest PO values. In the case of the DTT assay, we observed high PO values for NIST and ash pellet and, to a lower extend, for brake dust and coke. Very low PO values were instead obtained for the natural PM components (soil and Saharan dust) and for road dust. The AA assay showed, for the soluble fraction, a behaviour quite similar to the DDT assay, even though the relative PO values are different; the ash pellet produced the highest PO values, followed by brake dust, coke and NIST. 


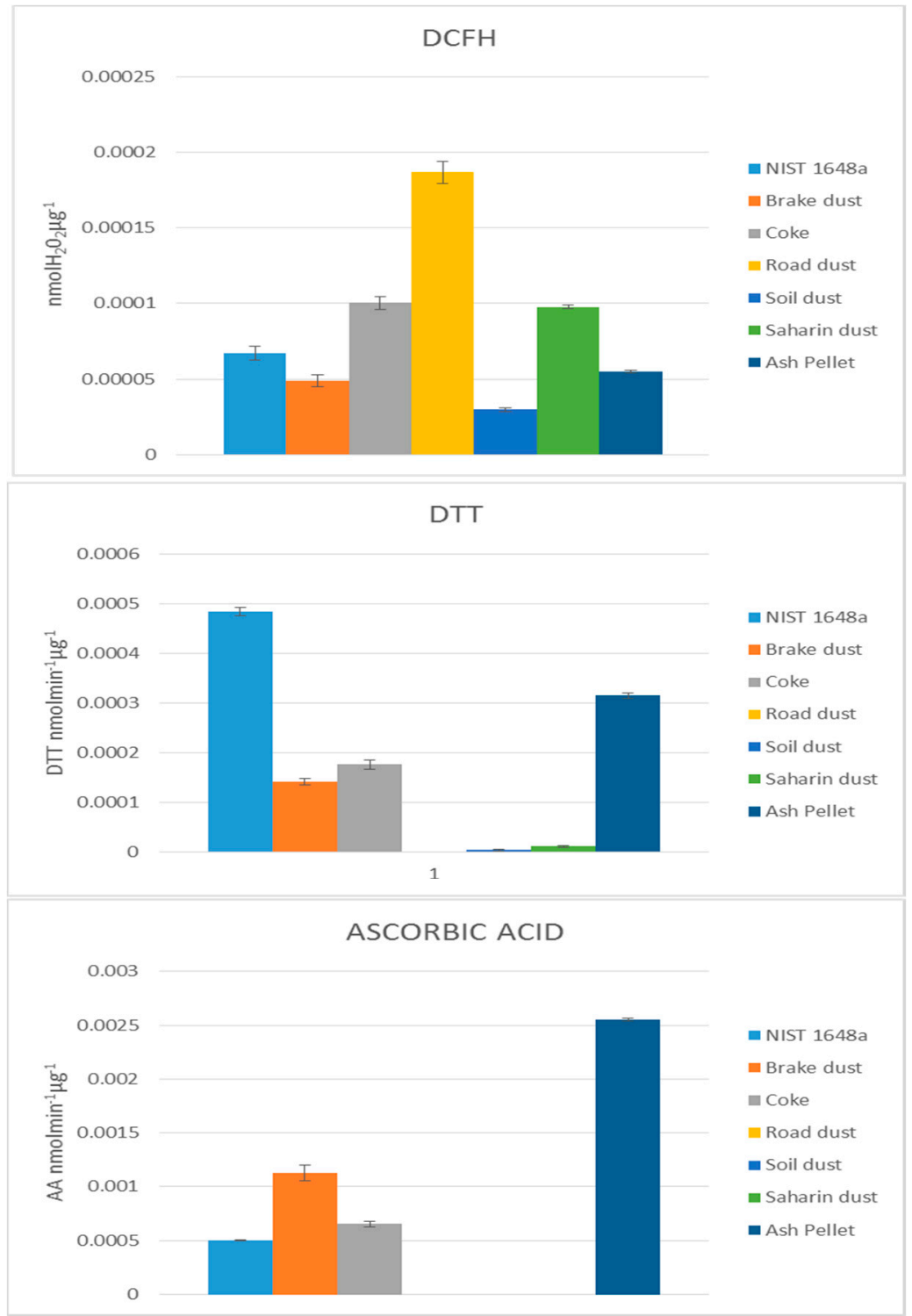

Figure 1. Oxidative potential analysis of soluble part with DCFH, DTT and AA methods.

In Figure 2, the PO values obtained for the insoluble fraction of PM are reported. It can be note, that the three $\mathrm{PO}$ assays considered have a contribution comparable for the insoluble species, or even higher, to the one related to the soluble species. This result is in agreement with a recent in vivo study showing that the insoluble fraction of elements, contained in the same seven dusts considered in the present study, was the main responsible for the oxidative stress induced in Echinogammarus veneris speciments [25]. It can also be note that, also in this case, the PO values obtained with the three methods are significantly different.

The result obtained by the DCFH assay presented very high PO values for the ash pellet (almost double than that measured in the soluble fraction), while the values measured for coke, soil dust and road dust were similar to those obtained in the soluble fraction. PO related to Saharan dust was, also for the insoluble fraction, very low.

In addition, PO deriving from the application of the DTT assay to ash pellet are very high, suggesting that emissions due to domestic biomass burning are potentially harmful for human health and environment. Even though the relative sensitivity was different respect to the DCHF results, relevant PO were, also in this case, measured for NIST, brake dust, coke, road dust and soil dust, while negligible values were measured for Saharan dust. 
Ascorbic acid method, also for the insoluble fraction, showed a very different behaviour, being particularly sensitive toward the insoluble fraction of brake dust and, to a lesser extent, of pellet ash and coke.

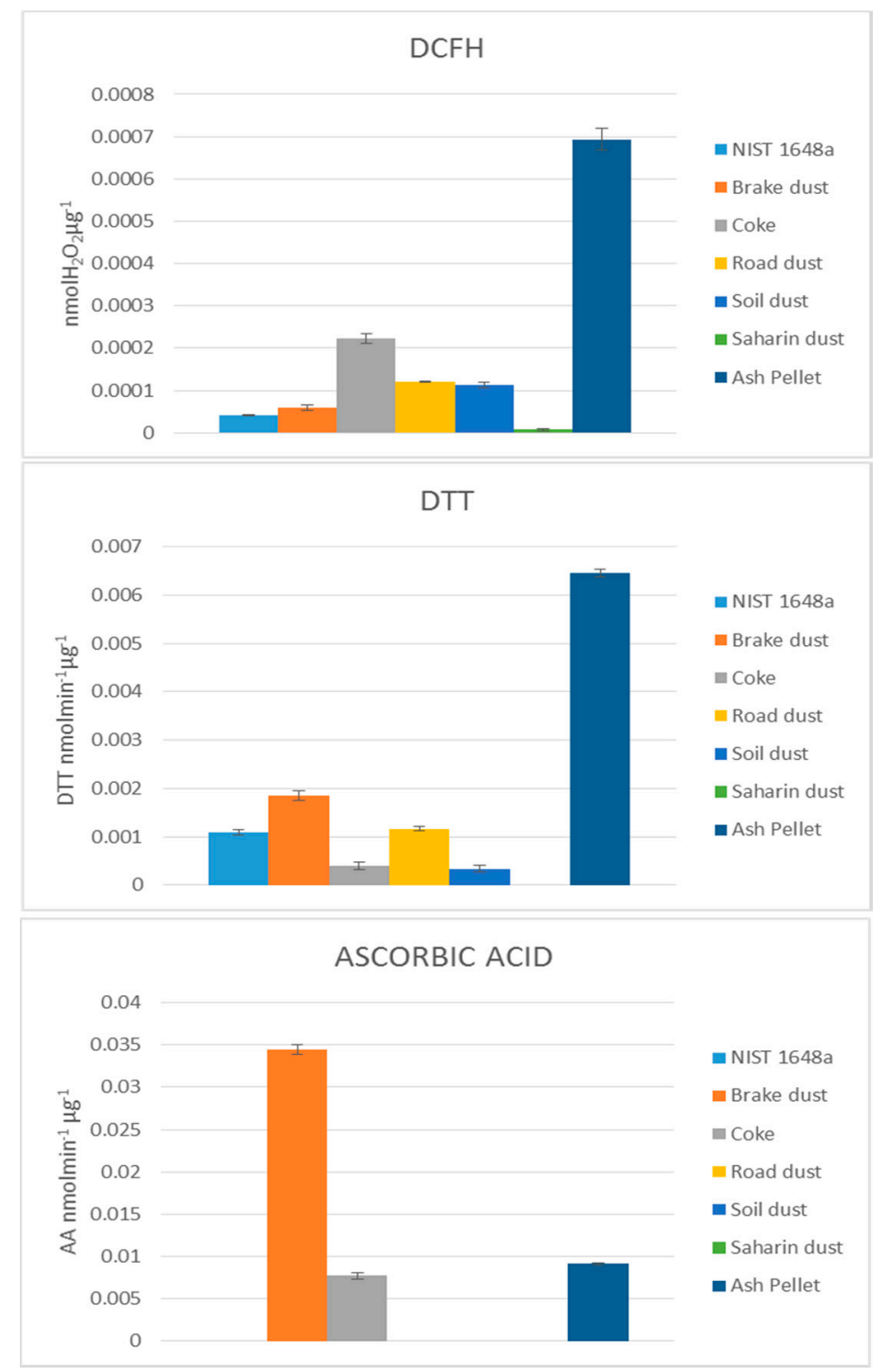

Figure 2. Oxidative potential analysis of insoluble fraction by DCFH, DTT and AA assays.

\section{Results of Principal Component Analysis}

In order to confirm the relationships between the results of the three PO assays and the chemicals characteristic of each dust, we studied the interrelations among the whole set of variables by Principal component Analysis (PCA). Also in this study, we decided to examine separately the data relative to the soluble fraction of the dust and those related the insoluble fraction. The values were obtained with column and row auto-scaling and column mean centering.

The plots relative to the soluble fraction reported in Figure 3 show the first two principal components, which are able to explain the $70 \%$ of the total variance and covariance explored. The loading plot (panel (a) in Figure 3) shows that there are three different clusters of variables, characterized by the presences of one of the PO assay each. This separation further confirms that the three methods have a selective affinity towards different chemical compounds and that they are noninterchangeable each other. 


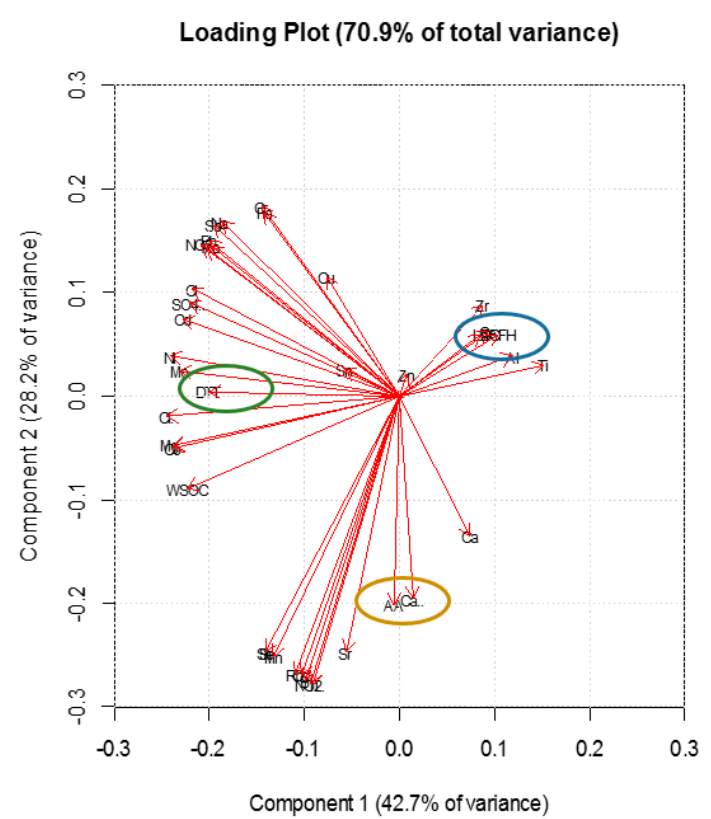

(a)

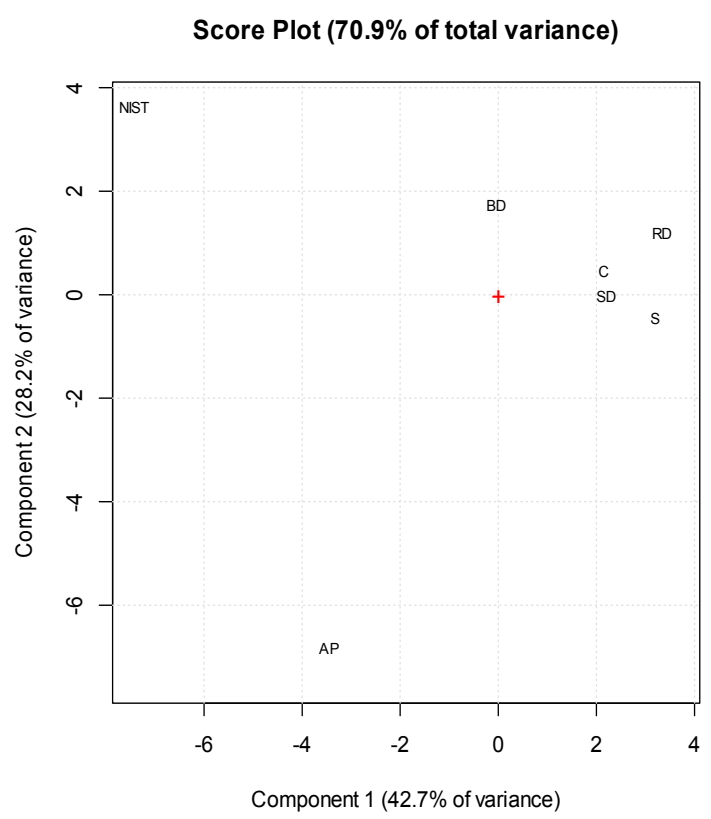

(b)

Figure 3. PCA analysis about soluble part of dusts.

In the acid ascorbic assay cluster, the most discriminating variables are $\mathrm{Mn}, \mathrm{Sr}, \mathrm{Rb}$, Se and $\mathrm{Ca}$ (away from the centre). The DTT assay is influences by several parameters, none of which seems to be particularly significant. The most important variables (near to DTT and away from the centre) are $\mathrm{Mn}, \mathrm{Ni}, \mathrm{Cl}^{-}, \mathrm{SO}_{4}{ }^{2-}, \mathrm{Cd}$ and WSOC. These variables allow for hypothesizing an influence due to combustive and secondary sources.

The DCFH assay seems to be more linked to crustal compound (typically characterized by element as $\mathrm{Ti}, \mathrm{Al}$ etc.), even though the cluster is nearer to the center of the plot and does not allow a good discrimination of the variables. A completely different behaviour was observed when the dataset relative to the insoluble fraction of dusts was examined. As shown in the loading plot (panel (a) of Figure 4), there are no specific clusters that correlate the three methods with specific chemical species. It can also be note that in this case the first two principal components are capable to explain only the $50 \%$ of the total explored variance and covariance. The correlations in this case are then much lower and difficult to interpret, probably because there are many hydrophobic species in these samples that had not been analysed in this work.

The presence of a great number of components that affect the total variability makes the study of the residual part very interesting. All this problematic motivates us to pursue the study by analysing more insoluble chemical species, which could provide new elements of correlation and more information about the mechanism followed by the three methods.

\section{Conclusions}

The oxidative potential of the selected dusts obtained by the three assays indicated that most of the PM components are potentially able to induce oxidative stress in living organisms. However, as different mechanisms are involved in generating ROS, none of the assays, applied singly, is able to successfully predict the capacity of PM of causing oxidative stress.

The DTT assay showed high sensitivity towards ash pellet and road dust and seemed to be influenced mainly by the organic compounds of the PM, including water-soluble organic carbon (WSOC), also in agreement to previous studies $[13,14]$. Organic compounds contain in fact species capable of catalysing the ROS generation by reactions that lead to the formation of superoxide radicals, which are probably responsible for the generation of oxidative potential. On the other way, the ascorbic acid assay is more sensitive to dusts rich of metals and metalloids, such as brake dusts 
and ash pellet. The DCFH assay showed a certain affinity to organic species, but seemed to be less selective then the other assays.

The second important result of this work is the confirmation of the relevant contribute of the insoluble fraction of dusts to their oxidative potential, independently from the assay applied. This is probably due to the presences of unknown organic species that need to be further investigated.

Future studies should be also focused to a deeper understanding of the relationship between the a-cellular OP assay and the in vivo biological effects.

Acknowledgments: The work was partially founded by Sapienza Università di Roma. The authors gratefully thank Melissa Marcoccia, Elena Rantica and Tiziana Sargolini for their support in chemical analysis and Lorenzo Massimi for the statistical evaluation of data.

Conflicts of Interest: The authors declare no conflict of interest.

$\begin{array}{ll}\text { Abbreviations } \\ \text { PM } & \text { Particulate Matter } \\ \text { ROS } & \text { Reactive Oxygen Species } \\ \text { OP } & \text { Oxidative Potencial } \\ \text { DTT } & \text { Dithiothreitol } \\ \text { DCFH } & 2^{\prime}, 7^{\prime} \text {-Dichlorofluorescin } \\ \text { AA } & \text { Acid Ascorbic } \\ \text { OC } & \text { Organic Carbon } \\ \text { IC } & \text { inorganic Ions } \\ \text { EC } & \text { Elemental Carbon } \\ \text { ICP-MS } & \text { Inductively Coupled Plasma- Mass Spectroscopy } \\ \text { PCA } & \text { Principal Component Analysis } \\ \text { NPOC } & \text { Non Purgeable Organic Carbon } \\ \text { WSOC } & \text { Water Soluble Organic Carbon }\end{array}$

\section{References}

1. Brunekreef, B.; Stephen, T.; Holgate, S.T.H. Air Pollution and Health. Lancet 2002, 360, 1233-1242, doi:10.1016/S0140-6736(02)11274-8.

2. Hoek, G.; Ranjini, M.K.; Beelen, R.; Peters, A.; Ostro, B.; Brunekreef, B.; Kaufman, J. Long-Term Air Pollution Exposure and Cardio-Respiratory Mortality: A Review. Environ. Health 2013, 12, 43, doi:10.1186/1476-069X-12-43.

3. Brook, R.D.; Rajagopalan, S.; Pope, C.A.; Brook, J.R.; Bhatnagar, A.; Diez-Roux, A.V.; Holguin, F.; Hong, Y.; Luepker, R.V.; Mittleman, M.; et al. Particulate Matter Air Pollution and Cardiovascular Disease an Update to the Scientific Statement From the American Heart Association. Circulation 2010, 121, 2331-2378, doi:10.1161/CIR. 0b013e3181dbece1.

4. Donaldson, K.; Stone, V.; Borm, P.J.; Jimenez, L.A.; Gilmour, P.S.; Schins, R.P.; Knaapen, A.M.; Rahman, I.; Faux, S.P.; Brown, D.M.; et al. Oxidative stress and calcium signaling in the adverse effects of environmental particles (PM10). Free Radic. Biol. Med. 2003, 34, 1369-1382, doi:10.1016/S0891-5849(03)00150-3.

5. Nel, A. Air pollution-related illness: effects of particles. Science 2005, 308, 804-806, doi:10.1126/science.1108752.

6. Shi, T.; Knaapen, A.M.; Begerow, J.; Birmili, W.; Borm, P.J.; Schins, R.P. Temporal variation of hydroxyl radical generation and 8-hydroxy-2'-deoxyguanosine formation by coarse and fine particulate matter. Occup. Environ. Med. 2003, 60, 315-321.

7. Shi, T.; Schins, R.P.; Knaapen, A.M.; Kuhlbusch, T.; Pitz, M.; Heinrich, J.; Borm, P.J. Hydroxyl radical generation by electron paramagnetic resonance as a new method to monitor ambient particulate matter composition. J. Environ. Monit. 2003, 5, 550-556.

8. Zielinski, H.; Mudway, I.S.; Berube, K.A.; Murphy, S.; Richards, R.; Kelly, F.J. Modeling the interactions of particulates with epithelial lining fluid antioxidants. Am. J. Physiol. 1999, 277, L719-L726.

9. Kelly, F.J.; Fussell, J.C. Size, Source and Chemical Composition as Determinants of Toxicity Attributable to Ambient Particulate Matter. Atmos. Environ. 2012, 60, 504-526, doi:10.1016/j.atmosenv.2012.06.039. 
10. Li, N.; Sioutas, C.; Cho, A.; Schmitz, D.; Misra, C.; Sempf, J.; Meiying, W.; Oberley, T.; Froines, J.; Nel, A. Ultrafine Particulate Pollutants Induce Oxidative Stress and Mitochondrial Damage. Environ. Health Perspect. 2003, 111, 455-460.

11. Sheesley, R.J.; Schauer, J.J.; Chowdhury, Z.; Cass, G.R.; Simoneit, B.R.T. Characterization of organic aerosols emitted from the combustion of biomass indigenous to South Asia. J. Geophys. Res. Atmos. 2003, 108, 4285, doi:10.1029/2002JD002981

12. Donaldson, K.; Stone, V.; Seaton, A.; MacNee, W. Ambient Particle Inhalation and the Cardiovascular System: Potential Mechanisms. Environ. Health Perspect. 2001, 109, 523-527.

13. Cho, A.K.; Sioutas, C.; Miguel, A.H; Kumagai, Y.; Schmitz, D.A.; Singh, M.; Eiguren-Fernandez, A.; Froines, J.R. Redox activity of airborne particulate matter at different sites in the Los Angeles Basin. Environ. Res. 2005, 99, 40-47.

14. Fang, T; Verma, V.; Bates, J.T.; Abrams, J.; Klein, M.; Strickland, M.J.; Sarnat, S.E.; Chang, H.H.; Mulholland, J.A.; Tolbert, P.E.; et al. Oxidative Potential of Ambient Water-Soluble PM2.5 in the Southeastern United States: Contrasts in Sources and Health Associations between Ascorbic Acid (AA) and Dithiothreitol (DTT) Assays. Atmos. Chem. Phys. 2016, 16, 3865-3879, doi:10.5194/acp-16-3865-2016.

15. Kumagai, Y.; Koide, S.; Taguchi, K.; Endo, A.; Nakai, Y.; Yoshikawa, T.; Shimojo, N. Oxidation of proximal protein sulfhydryls by phenanthraquinone, a component of diesel exhaust particles. Chem. Res. Toxicol. 2002, 15, 483-489, doi:10.1021/tx0100993.

16. Valko, M.; Morris, H.; Cronin, M.T. Metals, toxicity and oxidative stress. Curr. Med. Chem. 2005, 12, 11611208, doi:10.2174/0929867053764635.

17. Hung, H.F.; Wang, C.S. Experimental determination of reactive oxygen species in Taipei aerosols. J. Aerosol Sci. 2001, 32, 1201-1211.

18. Venkatachari, P.; Hopke, P.K.; Grover, B.D.; Eatough, D.J. Measurement of Particle-Bound Reactive Oxygen Species in Rubidoux Aerosols. J. Atmos. Chem. 2005, 50, 49-58.

19. Venkatachari, P.; Hopke, P.K.; Brune, W.H.; Ren, X.; Lesher, R.; Mao, J.; Mitchell, M. Characterization of Wintertime Reactive Oxygen Species Concentrations in Flushing, New York. Aerosol Sci. Technol. 2007, 41, 97-111, doi:10.1080/02786820601116004.

20. Lebel, C.P.; Ischiropoulos, H.; Bondy, S.C. Evaluation of the probe 2',7'-dichlorofluorescin as an indicator of reactive oxygen species formation and oxidative stress. Chem. Res. Toxicol. 1992, 5, 227-231.

21. Keston, A.S.; Brandt, R. The fluorometric analysis of ultramicro quantities of hydrogen peroxide. Anal. Biochem. 1965, 11, 1-5.

22. Wang, H.; Joseph, J.A. Quantifying cellular oxidative stress by dichlorofluorescein assay using microplate reader. Free Radic. Biol. Med. 1999, 27, 612-616.

23. Halliwell, B.; Whiteman, M. Measuring reactive species and oxidative damage in vivo and in cell culture: How should you do it and what do the results mean? Br. J. Pharmacol. 2004, 142, 231-255, doi:10.1038/sj.bjp.0705776

24. Chirizzi, D.; Cesari, D.; Guascito, M.R.; Dinoi, A.; Giotta, L.; Donateo, A.; Contini, D. Influence of Saharan Dust Outbreaks and Carbon Content on Oxidative Potential of Water-Soluble Fractions of PM2.5 and PM10. Atmos. Environ. 2017, 163, 1-8, doi:10.1016/j.atmosenv.2017.05.021.

25. Marcoccia, M.; Ronci, L.; De Matthaeis, E.; Setini, A.; Perrino, C.; Canepari, S. In Vivo Assesment of the Genotoxic and Oxidative Stress Effects of Particulate Matter on Echinogammarus Veneris. Chemosphere 2017, 173, 124-134, doi:10.1016/j.chemosphere.2017.01.019.

26. Pant, P.; Harrison, R.M. Estimation of the contribution of road traffic emissions to particulate matter concentrations from field measurements: A review. Atmos. Environ. 2013, 77, 78-97.

27. Canepari, S.; Perrino, C.; Olivieri, F.; Astolfi, M.L. Characterisation of the traffic sources of PM through sizesegregated sampling, sequential leaching and ICP analysis. Atmos. Environ. 2008, 42, 8161-8175.

28. Thorpe, A.; Harrison, R.M. Sources and properties of non-exhaust particulate matter from road traffic: A review. Sci. Total Environ. 2008, 400, 270-282.

29. Canepari, S.; Marconi, E.; Astolfi, M.L.; Perrino, C. Relevance of Sb (III), Sb (V), and Sb-containing nanoparticles in urban atmospheric particulate matter. Anal. Bioanal. Chem. 2010, 397, 2533-2542.

30. Goudie, A. Desert dust and human health disorders. Environ. Int. 2014, 63, 101-113. 
31. De Oliveira Alves, N.; Matos Loureiro, A.L.; Cavalcante dos Santos, F.; Halter Nascimento, K.; Dallacort, R.; De Castro Vasconcellos, P.; De souza Hacon, S.; Artaxo, P.; Batistuzzo de Medeiros S.R. Genotoxicity and composition of particulate matter from biomass burning in the eastern Brazilian Amazon region. Ecotoxicol. Environ. Saf. 2011, 74, 1427-1433.

32. Taioli, E.; Šrám, R.J.; Garte, S.; Kalina, I.; Popov, T.A.; Farmer, P.B. Effects of Polycyclic Aromatic Hydrocarbons (PAHs) in Environmental Pollution on Exogenous and Oxidative DNA Damage (EXPAH Project): Description of the Population under Study. Mutat. Res. 2007, 620, 1-6.

33. Vernile, P.; Tutino, M.; Bari, G., Amodio, M., Spagnuolo, M.; De Gennaro, G.; De Lillo, E. Particulate matter toxicity evaluation using bioindicators and comet assay. Aerosol Air Qual. Res. 2013, 13, 172-178.

34. Knaapen, A.M.; Shi, T.; Borm, P.J.; Schins, R.P. Soluble metals as well as the insoluble particle fraction are involved in cellular DNA damage induced by particulate matter. Mol. Cell Biochem. 2002, 1, 317-326.

35. Yi, S.; Zhang, F.; Qu, F.; Ding, W.; Water-insoluble fraction of airborne particulate matter (PM10) induces oxidative stress in human lung epithelial A549 cells. Environ. Toxicol. 2014, 2, 226-233, doi:10.1002/tox.21750.

36. Pietrodangelo, A.; Salzano, R.; Rantica, E.; Perrino, C. Characterisation of the local topsoil contribution to airborne particulate matter in the area of Rome (Italy). Source profiles. Atmos. Environ. 2013, 69, 1-14.

37. Huang, W.; Zhang, Y.; Zhang, Y.; Fang, D.; Schauer, J.J. Optimization of the Measurement of Particle-Bound Reactive Oxygen Species with 2',7'-dichlorofluorescin (DCFH). Water Air Soil Pollut. 2016, 227, 164, doi:10.1007/s11270-016-2860-9.

38. Canepari, S.; Astolfi, M.L.; Farao, C.; Maretto, M.; Frasca, D.; Marcoccia, M.; Perrino, C. Seasonal variations in the chemical composition of particulate matter: A case study in the Po Valley. Part II: Concentration and solubility of micro- and trace-elements. Environ. Sci. Pollut. Res. 2014, 21, 4010-4022.

(C) 2017 by the authors. Licensee MDPI, Basel, Switzerland. This article is an open access article distributed under the terms and conditions of the Creative Commons Attribution (CC BY) license (http://creativecommons.org/licenses/by/4.0/). 